\title{
ANALISIS STABILITAS DINAR EMAS DAN DOLAR AS DALAM DENOMINASI RUPIAH
}

\author{
Darwis Harahap ${ }^{I}$
}

\begin{abstract}
Stability Analysis of Gold Dinar and US Dollar in Rupiab Denomination. This study was aimed to (a) to know if there is a causality relation between Gold Dinar and U.S. Dolar, (b) to know that Gold Dinar more stabil than U.S. Dolar AS, (c) to know whether Gold Dinar can be alternative currency as a substitute for U.S. Dolar. The result is that the growth of Gold Dinar higher than U.S. Dolar, the result of Granger causality test shown that there was undirectional causality from Gold Dinar to U.S. Dolar. The result of Analysis of Variance (ANOVA) shown that U.S. than Dinar Gold more stabil Dolar AS that measured by Rupiah. From all of result tests, it can conclude that Gold Dinar can be a alternative currency instead of U.S. Dolar.
\end{abstract}

Keywords: Gold Dinar, Volatility, Granger Causality Test, ANOVA

\begin{abstract}
Abstrak: Analisis Stabilitas Dinar emas dan Dólar AS dalam Denominasi Rupiah. Penelitian ini bertujuan: (a) Untuk mengetahui apakah ada hubungan volatilitas antara Dinar emas dengan Dolar AS. (b). Untuk mengetahui apakah Dinar emas lebih stabil dari nilai tukar Dolar. (c) Untuk mengetahui apakah Dinar emas bisa menjadi alternatif nilai tukar untuk menggantikan Dolar AS. Hasil perhitungan laju pertumbuhan Dolar AS menunjukkan bahwa laju pertumbuhan Dinar emas per bulan lebih tinggi daripada laju pertumbuhan Dolar AS. Hasil Uji kausalitas Granger menunjukkan bahwa terjadi hubungan kausalitas searah antara harga Emas dan Dolar. Dari hasil uji analysis of variance (ANOVA) dapat diambil kesimpulan bahwa Dinar emas lebih stabil dari pada Dolar AS. Kesimpulannya, Dinar emas bisa dijadikan alternatif pengganti Dolar AS karena nilainya yang stabil yang diukur dengan Rupiah.
\end{abstract}

Kata kunci: Dinar Emas, Volatilitas, Uji Kausalitas Granger, ANOVA

${ }^{1}$ Diterima: 12April 2014, direvisi:, 15 Mei 2014, disetujui: 20 Mei 2014 IAIN PadangSidimpuan, Jl. H. Tengku Rizal Nurdin, Km. 4,5, Sihitang, Padangsidimpuan. Email: darwis05@yahoo.com 


\section{PENDAHULUAN}

Para pakar sepakat bahwa krisis moneter yang terjadi pada tahun 1997 penyebabnya adalah adanya tekanan rupiah yang dipicu oleh kegiatan spekulasi yang dilakukan para spekulan asing yang berawal dari Thailand. Financil panic yang terjadi di Thailand merembet ke berbagai negara, termasuk Indonesia (Siregar, 2002). Krisis ekonomi yang terjadi di kawasan Asia ini berawal dari krisis nilai tukar mata uang, yaitu semakin kuatnya mata uang asing -khususnya Dolar AS- terhadap mata uang domestik. Akibatnya harga-harga meningkat secara berlipat karena struktur ekonomi Indonesia didominasi impor, baik bahan baku maupun barang jadi. Di bidang jasa keuangan pun demikian, dan tingkat suku bunga meroket sehingga pada puncaknya pernah mencapai $90 \%$. Dunia usaha macet, tingkat pengangguran semakin besar, inflasi meninggi dan pertumbuhan yang negatif (Hakim, 2001).

Ketidakstabilan nilai mata uang ini terhadap ekonomi secara khusus telah menyebabkan kejatuhan nilai mata uang di berbagai negara Asia, seperti Thailand, Malaysia, Indonesia, Fhilipina dan Korea Selatan yang mengakibatkan modal swasta lari keluar sejak 1997. investor telah menaburkan dananya secara besar-besaran ke negara Asia pada semester I dan menarik dananya pada musim panas. Diyakini sekitar US\$ 100 milyar arus dana bersih keluar dari daerah itu yang merupakan kejutan atau shock, jumlah ditaksir 10\% dari GDP dari 5 negara tersebut.

Akibat dari ketidakstabilan nilai tukar yang ditandai dengan volatilitas nilai tukar mempengaruhi tingkat ekspor di berbagai negara-negara berkembang. Esquivel and Larrain (2002) telah melakukan penelitian dampak Volatilitas Nilai Tukar G-3 pada negara-negara berkembang. Hasil yang diperoleh menunjukkan bahwa kenaikan volatilitas 1 persen pada negara-negara berkembang akan mengurangi ekspor negara-negara berkembang sebanyak dua persen, selain itu hasil pengujian di beberapa negara menunjukkan bahwa peningkatan volatilitas satu persen juga akan berdampak negatif terhadap masuknya investasi asing ke dalam negeri.

Krisis moneter terjadi pada dasarnya disebabkan fungsi uang tidak lagi hanya sebagai alat tukar dan alat untuk berjaga-jaga (precautionary motive) tetapi telah menjadi kegiatan spekulatif untuk mencari keuntungan pada saat nilai tukar rupiah melemah terhadap Dolar AS. Negara-negara yang terkena krisis moneter tersebut melakukan berbagai kebijakan ekonomi untuk keluar dari keterpurukan tersebut. Namun, kebijakan moneter yang dilakukan berlandaskan kebijakan ekonomi konvensional ternyata tidak mampu menyelesaikan krisis ini.

Menurut Chapra (2000), penyelesaian terhadap masalah ekonomi tidak pada akar masalah tapi hanya sebatas gejala, seperti ketidakseimbangan anggaran, ekpansi moneter yang berlebihan, defisit neraca pembayaran yang begitu besar, naiknya kecenderungan proteksionis, tidak memadainya bantuan asing, dan kerja sama 
internasional yang tidak mencukupi.

Dalam sejarah ekonomi, baru pada tahun 1990-an inilah krisis mata uang muncul kembali setelah menimpa Amerika pada tahun 1973. Kali ini negaranegara yang terkena adalah negara-negara selain Amerika dan Eropa, terutama Asia. Sebelumnya ketika Bretton Wood Agreement masih diikuti, dimana setiap mata uang harus dirujuk kepada emas, belum pernah terjadi krisis seperti ini. Ketika Amerika di bawah Nixon yang kemudian membatalkan perjanjian Bretton Wood tersebut pada tahun 1971 ketika Dolar AS semakin lemah dan ekonomi Amerika mengalami krisis. Sejak saat itu Dolar AS tidak lagi didasarkan kepada emas. Dengan demikian ekonomi dunia secara praktis telah dikuasai oleh Amerika, mengingat mata uang rujukan dunia saat ini adalah Dolar AS, sedangkan mata uang tersebut sepenuhnya diatur oleh pemerintah Amerika (Hakim, 2001).

Sejak berlakunya standard uang teratur (managed money standard) terlihat dua fenomena yang terjadi, yaitu tingginya tingkat inflasi dan tidak stabilnya nilai tukar. Selain itu kebijakan tersebut akan menimbulkan transaksi-transaksi maya di pasar uang. Hal inilah yang merupakan salah satu penyebab terjadinya krisis mata uang karena tersedianya jumlah uang yang cukup besar namun tidak didukung oleh nilai instrinsiknya.

Krisis ekonomi yang melanda Indonesia dan belahan lain, dipicu oleh dua sebab utama. Pertama, persoalan mata uang dimana nilai mata uang suatu negara saat ini terikat kepada mata uang negara lain (misalnya Rupiah terhadap US Dolar), tidak pada dirinya sendiri sehingga nilainya tidak stabil, dan jika mata uang tertentu bergejolak, pasti mempengaruhi kestabilan mata uang tersebut. Kedua, kenyataan bahwa uang tidak lagi dijadikan sebagai alat tukar saja, tapi juga sebagai komoditi yang diperdagangkan (dalam bursa valuta asing) dan diambil keuntungan (interest) alias bunga atau riba dari setiap transaksi peminjaman atau penyimpanan uang (Yusanto, 2001). Terjadinya krisis mata uang ini memicu negara-negara di Asia untuk mengkaji kembali penggunaan uang kertas (fiat money) yang dipakai saat ini dengan penggunaan kembali Dinar emas.

Gagasan awal dilakukan pada suatu konferensi pada bulan Agustus 2002 dengan tema: "Stable and Just Globar Monetary System menghasilkan penerapan Dinar emas pada transaksi perdagangan luar negerinya dengan mitra dagang melalui Pengaturan Pembiayaan Bilateral (Billateral Payment Arrangement) atau BPA. Gagasan tersebut dilanjutkan pada seminar di Kuala Lumpur tanggal 2223 Oktober 2002 dengan tema: "The Gold Dinar in Multilateral Trade" dengan menyetujui usulan Kepala Bank Sentral Iran, Bijan Latif untuk membentuk suatu sekretariat yang ditugasi mengkoordinir pengembangan kebijaksanaan Dinar islami (Perwaatmadja, 2003). 
Hasil Sidang ke-27 Dewan Gubernur Islamic Develpment Bank (IDB) tanggal 22-23 oktober 2002 di Ouagadougu-Burkin Faso, delegasi Malaysia dipimpin oleh Deputi Menteri keuangan Syafie Mohd Salleh telah mengajak negara anggota IDB, termasuk Indonesia menerima konsep perdagangan dengan mempergunakan Dinar emas untuk memfasilitasi dan meningkatkan perdagangan antar negara anggota dan mitra dagang lainnya. Dan konferensi di Kuala Lumpur tgl 2-3 november 2002, Indonesia telah menjadi salah satu negara pendiri the Islamic Financial Service Board (IFSB) bersama-sama dengan Bahrain, Iran, Kuwait, Malaysia, Pakistan, Saudi Arabia, Sudan, Uni Emirat Arab dan Islamic Development Bank (IDB). Dalam konferensi ini antara lain dibahas penerapan penting dari Bank Sentral dalam penerapan Dinar emas pada penyelesaian Pembayaran Sistem perdagangan Bilateral dan Multilateral.

Alasan penggunaan dinar emas sebagai alat transaksi keuangan disamping nilainya yang stabil, penggunaan dinar akan mengurangi ketergantungan keuangan (financial dependensi) para penggunanya terhadap Dolar AS akibat mismanajemen modal. Hal ini dapat dilihat dalam dunia perdagangan internasional. Negara yang memiliki neraca perdagangan defisit (mayoritas dunia Muslim) berarti jumlah dana dalam negeri lebih banyak mengalir ke luar negara ketimbang dana asing yang masuk ke dalam negara. Dengan kata lain, jumlah impor jauh lebih besar dari pada jumlah ekspor. Terjadinya capital flight yang tinggi menyebabkan devisa negara akan turun, kalaupun tidak minus. Bila ini terjadi, maka untuk menutupi defisit anggaran negara terpaksa harus didanai dengan hutang luar negeri. (Majid, 2005)

Keterpaksaan berhutang jelas telah memerangkapkan negara penghutang terhadap keharusan untuk memenuhi semua persyaratan yang ditetapkan negara donor (pemberi hutang), yang sifatnya sangat mencekik leher negara penghutang. Keharusan menggunakan Dolar AS ketika membayar hutang akan menyebabkan nilai uang negara penghutang semakin rendah. Konsekuensinya, negara penghutang berada di pihak yang dirugikan karena harus membayar hutang dalam jumlah yang lebih banyak dibandingkan dengan jumlah hutang yang sesungguhnya. Ini sematamata karena ketidakstabilan (apresiasi) nilai Dolar. (Majid, 2005)

Kestabilan dinar emas akan mengeliminir upaya-upaya spekulasi di pasar Valas. Penggunaan uang hampa telah menyebabkan tindakan spekulatif di sebagian besar transaksi valas. Hal ini sebagaimana disebutkan Lietaer (1997) dalam makalahnya yang dipresentasikan dalam International Forum on Globalisation (IFG) sebagai berikut: "pada tahun 1975, sekitar 80\% dari transaksi di pasar valas adalah melibatkan aktivitas bisnis sektor riel, yaitu transaksi yang benar-benar menghasilkan barang dan jasa dan sisanya $20 \%$ bersifat spekulatif. Hari ini, transaksi di pasar valas yang melibatkan sektor riel turun menjadi $2.5 \%$ dan selebihnya $97.5 \%$ 
adalah transaksi spekulatif". Penggunaan dinar emas diyakini akan menutup semua gerak para spekulan untuk meraup keuntungan di pasar Valas melalui aktivitas arbitraging.

Volatilitas nilai tukar Dolar AS telah menyebabkan instabilitas ekonomi di berbagai negara-negara berkembang. Hal ini dibuktikan di berbagai negara berkembang yang menunjukkan bahwa kenaikan volatilitas pada negara-negara berkembang akan mengurangi ekspor negara-negara berkembang. Selain itu, fenomena instabilitas uang kertas yang didominasi Dolar AS telah menyebabkan fluktuasi nilai tukar sehingga menyebabkan inflasi yang terus menerus juga menyebabkan nilai tukar rupiah terus mengalami depresiasi. Devaluasi nilai mata uang memberikan pengaruh yang signifikan terhadap pendapatan dan harga-harga barang dan jasa. Devaluasi juga menyebabkan membengkaknya nilai utang jangka pendek yang dihitung dengan kurs Dolar AS.

Penggunaan nilai tukar Dolar AS sebagai alat transaksi perdagangan dunia telah menyebabkan ketergantungan perekonomian terhadap Amerika Serikat. Dominasi Dolar AS sebagai standar global dalam setiap aktivitas perdagangan global, eksporimpor, atau hutang piutang semakin sulit diprediksi. Hal ini disebabkan nilai tukar Dolar AS terus mengalami fluktuasi sehingga menyebabkan gejolak ekonomi dan memiliki dampak yang sangat signifikan terhadap stabilitas perekonomian. Fluktuasi nilai tukar Dolar AS yang demikian cepat semakin menjadikan perekonomian global sangat sulit diprediksi

Adanya instabilitas nilai tukar Dolar AS maka diperlukan mata uang stabil. Dalam sejarah telah terbukti bahwa dinar emas stabil dan tidak pernah mengalami inflasi, sementara sejak perjalanan uang kertas atau uang hampa (fiat money) terus mengalami fluktuasi dan depresiasi. Untuk itu, penggunaan mata uang dinar emas yang berbahan utama Emas 22 karat diharapkan dapat menyelamatkan stabilitas mata uang.

\section{TINJAUAN PUSTAKA}

Dalam Islam fungsi uang mencakup tiga hal, penyimpan nilai (store of value), alat tukar (medium of exchange), alat pengukur nilai (unit of account). Sebagai fungsi alat tukar (medium of exchange) dan alat pengukur nilai (unit of account) telah dilakukan oleh fiat money, tetapi peran fiat money sebagai penyimpan nilai (store of value) akan berbeda dalam ekonomi Islam. Menurut Syariah, uang itu sendiri tidak dapat diperoleh keuntungan (interest). Menyimpan uang sebagai penyimpan nilai (store of value) akan terkikis keseimbangan rielnya karena inflasi dan pembayaran zakat (Habib, 2002). 
Dalam Islam memegang uang hanya untuk transaksi dan menginvestasikan kelebihan dana pada asset untuk mendapatkan keuntungan. Ketika tingkat bagi hasil meningkat maka akan diperoleh subtitusi dari uang terhadap asset-asset tersebut. Dalam ekonomi konvensional, fungsi uang tidak lagi menujukkan esensinya sebagai alat penyimpan nilai karena itu terjadi fluktuasi, maka dalam Islam, stabilitas nilai uang sangat penting dan objek fundamental dalam sebuah sistem ekonomi Islam. Dalam Islam, stabilitas nilai tukar pada close economy berimplikasi pada ketiadaan bunga (interest). Mempostulasikan permintaan uang dalam Islam berhubungan positif dengan agregat output $Y$ (yang muncul dari tujuan-tujuan transaksi) dan sebaliknya pada tingkat bagi, $r$ pada aset (yang muncul dari alasan penyimpan nilai). Perubahan tingkat bagi hasil sebagai ganti bunga pada fungsi permintaan uang berbeda dalam ekonomi Islam. Sebab permintaan uang dalam Islam tidak ada subtitusi antara uang dan bunga seperti pada obligasi dan derivatif (forward, futures, option dan lain-lain).

Persamaan penawaran uang di bank Sentral dalam ekonomi islam sebanding dengan emas dan aset atau klaim terhadap uang. Bank dapat meningkatkan penawaran uang dengan menaikkan salah satu dari tiga komponen asetnya. Kemampuan Bank Islam untuk menciptakan uang melalui penciptaan kredit juga terbatas. Bank Islam hanya membiayai transaksi yang didukung oleh barang-barang riel dan aset atau menginvestasikan pada proyek dengan dasar frofit-sharing. Bank Islam tidak bisa membiayai semata-mata transaksi keuangan seperti membeli obligasi dan yang berhubungan dengan derivatif. Jadi, kemampuan bank Islam uutuk menciptakan uang lebih kecil dari bank konvensional sebagaimana harus berhubungan dengan ekonomi riil.

Untuk menentukan nilai tukar harus digunakan sebuah model moneter konvensional yang merepresentasikan model krisis keuangan generasi pertama. Kegunaan dari model ini adalah modelnya sederhana dan dapat digunakan untuk mendiskusikan pengaruh model tersebut dan kebijakan fiskal (pembiayaan defisit) terhadap nilai tukar. Model moneter yang dipresentasikan berikut adalah versi modifikasi dan perluasan yang digunakan oleh Flood dan Marrion (1998) dan Frankle dan Rose (1995). Ekonomi menurut pertimbangan mereka dianggap kecil dan terbuka.

Kita akan menggunakan dua kondisi keseimbangan untuk menghubungkan ekonomi di seantero dunia. Dua teori tentang penentuan nilai nilai tukar (exchange rate) diturunkan dari kondisi arbitrase (arbitrage) yang secara luas digunakan dalam open economy dalam ekonomi makro. Pertama, berhubungan dengan arbitrase dalam pasar barang purchasing power parity (PPP) atau paritas daya beli. Arbitrase (arbitrage) adalah pembelian dan atau penjualan secara simultan secara simultan atas 
barang yang sama di dalam dua pasar atau lebih dengan harapan akan memproleh laba dari perbedaan harga, Suwarno dkk: 2003. PPP telah berkembang menjadi salah satu teori-teori pokok penentuan nilai tukar dengan fiat money. Dengan PPP, nilai tukar ditentukan oleh arbitrage sebagai rasio tingkat harga (tingkat inflasi) dari dua negara. Kedua, arbitrage berhubungan dengan pasar aset finansial dan disebut the (uncover) interest parity (IP) atau paritas bunga (terbuka). Dengan mobilitas modal dan tanpa biaya-biaya transaksi, modal jangka pendek (short term capital) mengalir melewati batas-batas untuk memperoleh tingkat keuntungan yang tinggi. Mobilitas modal memberikan kesamaan tingkat return melewati batas.

Flood dan Marion (1998) mendiskusikan bagaimana para spekulan melancarkan sebuah serangan terhadap nilai tukar ketika kebijakan moneter ekspansif yang tidak ditopang oleh cadangan dilakukan dalam sebuah ekonomi. Para spekulan aktif dalam pasar-pasar uang untuk mengangambil keuntungan untuk pergerakan-pergerakan nilai tukar yang akan datang. Perubahan-perubahan dalam ekpektasi depresiasi/appresiasi nilai tukar mempengaruhi permintaan uang dan juga sebagai nilai tukar. Andaikan sebuah ekonomi dengan rejim nilai tukar tetap dimana pemerintah menjalankan defisit anggaran yang dibiayai oleh bank Sentral. Pembiayaan defisit meningkatkan penawaran uang yang menciptakan tekanan pada nilai tukar untuk terdepresiasi.

Untuk menjaga nilai tukar pada nilai par maka Bank Sentral harus menjual cadangan. Para spekulan mengharapkan depresiasi pada mata uang domestik dan membeli nilai tukar luar negeri (cadangan yang dijual oleh Bank Pemerintah) pada pasar spot dan penjualan jangka pendek nilai tukar domestik di pasar futurelforward. Sebuah ekpektasi terhadap depresiasi nilai tukar domestik, akan menurunkan permintaan akan nilai tukar domestik

Untuk menjaga penawaran uang sejajar dengan permintaan yang rendah maka bank Sentral perlu untuk menjual lebih banyak cadangan. Sebuah stagnasi akan muncul ketika cadangan melemah. Dalam hal ini, nilai par nilai tukar tidak dapat dijaga lagi dan nilai tukar menjadi collapse. Ekspektasi para spekulan terealisir dan mereka memperoleh keuntungan.

Dari kebijakan yang dilakukan di atas masih belum dapat untuk menyelesaikan masalah ekonomi karena penyelesaian belum menyentuh akar permasalahan. Saat ini, kestabilan nilai tukar ditentukan oleh Dolar ASAmerika sebagai mata uang internasional, sebagai konsekuensi ketergantungan transaksi perdagangan yang telah dilakukan selama ini sehingga seluruh transaksi perdagangan dilakukan dengan Dolar. Untuk itu, untuk mengurangi demand for Dolar AS perlu dilakukan alat transaksi alternatif, yaitu mata uang emas sehingga permintaan terhadap Dolar AS akan menurun dan dengan sendirinya akan menstabilkan nilai tukar rupiah. 
Dalam Islam fungsi uang hanya sebagai medium of exchange dan bukan suatu komoditas yang bisa dijualbelikan dengan mengambil keuntungan secara on the spot maupun bukan. Suatu karakteristik uang yang terpenting adalah bahwa uang bukan untuk dikonsumsi, ia tidak diperlukan untuk dirinya sendiri, tapi merupakan sarana yang diperlukan untuk membeli barang untuk memenuhi kebutuhan manusia. Sebagaimana dijelaskan oleh Imam Ghazali bahwa emas dan perak hanyalah logam yang di dalam substansinya (zatnya itu sendiri) tidak ada manfaatnya atau tujuantujuannya. Menurut beliau, "kedua-duanya tidak memiliki apa-apa tetapi keduanya berarti segala-galanya". Keduanya ibarat cermin, ia tidak memiliki warna namun ia bisa mencerminkan semua warna.

Pada umumnya para ulama dan ilmuwan sosial Islam menyepakati fungsi uang sebagai alat tukar saja. Deretan ulama ternama seperti Imam Ghazali, Ibnu Taymiyyah, Ibnul Qayyim al-Jauziyyah, Ar-Raghib al-Ashbahani, Ibnu Khaldun, al-Maqrizi dan Ibnu Abidin dengan jelas menandaskan fungsi pokok uang sebagai alat tukar. Bahkan Ibnul Qayyim mengecam sistem ekonomi yang menjadikan fulus (mata uang logam dari kuningan atau tembaga) sebagai komoditas biasa yang bisa diperjualbelikan dengan kelebihan untuk mendapatkan keuntungan. Seharusnya mata uang itu bersifat tetap, nilainya tidak naik dan turun.

Marthon (2003), menyatakan uang selain berfungsi sebagai standar nilai dan satuan hitung, alat pembayaran (medium of exchange), dan alat penyimpan kekayaan (bukan penimbun kekayaan), menambahkan lagi bahwa fungsi uang sebagai alat pembayaran zakat dan kewajiban lainnya.

Sesuai yang dikemukakan Saidi (2003) bahwa uang kertas yang saat ini nilainya berfluktuasi menyebabkan nilainya tidak tetap. Sedangkan zakat harus dibayar sesuai dengan harta itu sendiri, seperti hewan ternak, hasil pertanian, hasil tambang dan sebagainya. Demikian juga dengan Emas dan perak merupakan nilai sejati dari harta, maka pembayaran zakat harta itu pun hanya sah bila dibayarkan dengan harta itu juga yakni Emas dan perak. Hal ini dapat dibuktikan pada zaman Kekhalifahan Usmaniah, ketika uang kertas telah lazim dipakai, pembayaran zakat mal hanya dibolehkan dengan Emas dan perak.

\section{METODE}

Data yang dikumpulkan adalah data harga rata-rata Emas 24 karat dan harga rata-rata Dolar AS. Data tersebut diperoleh dari Buletin Statistik Bulanan di Badan Pusat Statistik (BPS) Jakarta-Indonesia.

1) Data indeks harga Emas yang diperoleh dari perkembangan harga rata-rata valuta asing dan Emas di pasaran Jakarta. Data yang diperoleh adalah perkembangan rata-rata bulanan selama 67 bulan, mulai Januari 2001 sampai dengan tahun Juli 
2006.

2) Data indeks nilai Dolar AS yang diperoleh dari perkembangan harga ratarata valuta asing dan Emas di pasaran Jakarta. Data yang diperoleh adalah perkembangan rata-rata bulanan selama 67 bulan mulai Januari 2001 sampai dengan tahun Juli 2006.

3) Indeks harga konsumen (Consumer Price Index) yang diperoleh dari perkembangan indeks umum IHK di pasaran Jakarta. Data yang diperoleh adalah perkembangan rata-rata bulanan selama 67 bulan mulai Januari 2001 sampai dengan tahun Juli 2006.

4) Sebagai proksi Dinar emas, variabel Dinar emas adalah Indeks Harga Consumen (IHK) dibagi 100 kemudian dikalikan dengan harga emas maka diperoleh nilai riil emas.

Teknik analisis yang dipergunakan dalam penelitian ini ialah menggunakan Uji kausalitas Granger. Uji ini digunakan untuk menganalisis apakah ada hubungan volatilitas antara Dinar emas dengan Dolar AS. Sedangkan untuk menganalisis apakah Dinar emas lebih stabil dari nilai tukar Dolar dipergunakan uji ANOVA.

\section{PEMBAHASAN}

Berdasarkan data harga emas dan Dolar AS yang ada didapat trend masingmasing variabel penelitian. Variabel Dolar AS mempunyai trend naik turun dihitung dari data bulanan dari tahun 2001-2006. Kenaikan nilai Dolar AS mengalami volitiltas tingkat yang kecil. Kenaikan yang signifikan terjadi pada masa krisis 1998 , namun, data tersebut tidak termasuk dalam penelitian ini karena tidak ekonomi dalam keadaan tidak normal. Lain halnya yang terjadi sebelum krisis moneter. Variabel Dolar AS mengalami stabilitas yang cukup baik walaupun terjadi fluktuasi namun tidak begitu signifikan.

Sementara itu, variabel emas mempunyai trend yang lebih stabil dalam volatilitasnya dalam beberapa bulan mulai tahun 2001-2006. Namun, lain halnya dengan Dolar AS, kenaikan harga emas signifikan pada saat-saat tertentu dan kemudian stabil dalam jangka waktu yang lama. Begitu juga hal yang terjadi sebelum krisis moneter, dimana trend harga emas stabil dalam waktu yang lama kemudian naik secara signifikan dan kemudian stabil dalam waktu yang lama.

Dari analisis model pertumbuhan yang diperoleh dari data emas dan Dolar AS diperoleh persamaan sebagai berikut:

$$
\begin{array}{ll}
\text { Dinar }= & 10.989+0.017 \text { BULAN } \\
S E & (0.010)(0.00) \\
R^{2} & : 0.931
\end{array}
$$


Pengolahan regresi dengan menggunakan metode ordinary least square (OLS) hasil dari transformasi regresi non-linear menjadi regresi linear dalam bentuk model fungsional dalam bentuk log-lin. Prinsip model ini yaitu melakukan transformasi logaritma terhadap data. Model log-lin pada data ini, yaitu untuk mengetahui variabel emas dalam bentuk logaritma dan variabel BULAN dalam bentuk linear.

$\mathrm{R}^{2}$ untuk persamaan di atas cukup kuat, yaitu 93\% artinya variabel LEmas mampu menerangkan variabel BULAN sebesar 93\% sedangkan 7\% lagi dijelaskan oleh variabel lain yang tidak terdapat dalam model.

Sementara dari uji t pada variabel BULAN sebesar 488.410. Variabel BULAN secara signifikan berpengaruh terhadap variabel harga riil emas. Secara singkat dapat dengan melihat besarnya nilai probabilitas yang signifikan ditampilan oleh E-views.

Variabel BULAN mempunyai tanda positif, hal ini menunjukkan bahwa hubungan antara variabel BULAN dengan LNEMAS adalah positif. Ini menandakan bahwa apabila setiap BULAN maka harga emas akan meningkat.

Nilai uji F yang didapatkan 882.456 signifikan pada tingkat 5\%, hal ini karena nilai $\mathrm{F}$ hitung lebih besar daripada nilai $\mathrm{F}$ tabel. Hal ini memperlihatkan bahwa seberapa besar pengaruh variabel independen yang ada berpengaruh secara bersama-sama terhadap variabel dependen. Ini dapat ditunjukkan dengan nilai probabilita yang signifikan sebesar 0.00 yang ditampilkan oleh program E-views.

Model tersebut menyatakan bahwa $\alpha_{2}=0.017$. Artinya, pertumbuhan harga Emas per BULAN sekitar 1.7\% pada periode Januari 2001 - Juli 2006.

Adapun untuk pertumbuhan Dolar AS per bulan dapat dilihat dari hasil output, diperoleh persamaan regresi sebagai berikut:

$$
\begin{array}{rlrl}
\text { LDolar }= & 9.014+0.004 \text { BULAN } \\
& \text { SE } & .005 & 0.000 \\
\mathrm{R}^{2} & : 92 \%
\end{array}
$$

Hasil pengolahan data pada persamaan laju pertumbuhan nilai Dolar AS di atas diperoleh nilai uji t pada variabel BULAN sebesar 28.072. Variabel Bulan secara signifikan berpengaruh terhadap variabel LEmas. Secara singkat dapat dengan melihat besarnya nilai probabilitas yang ditampilan oleh E-views.

Variabel Bulan mempunyai tanda positif, hal ini menunjukkan bahwa hubungan antara variabel Bulan dengan LUSD adalah positif. Ini menandakan bahwa setiap Bulan harga Emas meningkat.

Nilai uji F yang didapatkan 788.017 signifikan pada tingkat 5\%, hal ini karena nilai $\mathrm{F}$ hitung lebih besar daripada nilai $\mathrm{F}$ tabel. Hal ini memperlihatkan 
bahwa seberapa besar pengaruh variabel independen yang ada berpengaruh secara bersama-sama terhadap variabel dependen. Ini dapat ditunjukkan dengan nilai probabilitas yang ditampilkan.

Koefisien determinasi $\left(\mathrm{R}^{2}\right)$ yang didapat dalam persamaan ini adalah $92 \%$. Koefisien determinasi yang didapat dari persamaan diatas menandakan bahwa variabel BULAN mampu menerangkan variabel LDolar ASsebesar 92\%. Sedangkan $8 \%$ lainnya diterangkan oleh variabel lain yang tidak terdapat dalam model.

Hasil output pengolahan regresi pada variabel LDolar AS di atas dengan menggunakan metode ordinary least square (OLS) menunjukkan bahwa laju pertumbuhan Dolar AS per Bulan sekitar 0.4\% pada periode periode Januari 2001 - Juli 2006, hal ini dilihat dari koefisien variabel BULAN.

Dari hasil pengalahan data pada variabel harga emas dan Dolar AS di atas, trend laju pertumbuhan emas dan Dolar AS menunjukkan bahwa pertumbuhan harga emas lebih tinggi dari pada harga Dolar AS. Artinya, secara rata-rata pergerakan harga riil emas lebih cepat daripada pergerakan harga Dolar AS. Diduga, volatilitas harga emas lebih tinggi daripada harga Dolar AS. Untuk melihat tingkat volatilitas harga emas dan Dolar AS, maka selanjutnya dilakukan uji variansi berikutnya.

Setelah melihat trend pertumbuhan harga riil Emas dan Dolar AS di atas maka selanjutnya akan dilihat pola hubungan antara harga riil emas dan Dolar AS dengan Uji Kausalitas Granger. Sebelum melakukan uji kausalitas Granger, sebagai syarat utama data harus stasioner. Maka dilakukan uji stasioneritas data.

Satu hal yang sering muncul pada data time series adalah stasioneritas data. Data runtut waktu dalam ekonomi pada umumnya memiliki volatilitas yang tinggi tidak stasioner pada level. Kondisi data yang tidak stasioner ini dapat digunakan dengan menggunakan grafik, correlogram, maupun unit root test.

Data stasioner merupakan syarat utama karena jika pada data yang tidak stasioner dilakukan regresi maka yang hasil yang diperoleh akan bersifat spurious, nonsense regression, atau miss leading yakni signifikan secara statistik namun tidak memiliki arti secara ekonomi. Untuk itu, langkah utama yang dilakukan adalah melakukan uji akar unit atau unit root test/uji derajat integrasi dan juga dengan metode grafik. Dimana untuk metode grafik ini, plot data dari masing-masing variabel dapat dilihat pada lampiran 1.

Untuk mendukung hasil pengamatan visual terhadap stasioneritas data, maka selanjutnya dilakukan uji akar unit. Uji akar unit dapat dilakukan dengan Dickey Fuller Test, Augmented Dickey Fuller Test dan Philip Peron Test (PP). Stasioner atau tidaknya data dapa dilihat dari nilai ADF/PP. Jika dari nilai ADF/PP lebih besar dari Mc Kinnon critical value pada tingkat signifikansi tertentu (1\%, 5\% maupun 10\%), 
berarti data dapat dikatakan stasioner.

Berdasarkan uji stasionaritas yang dilakukan terlihat bahwasanya variabel emas stasioner pada tingkat level karena nilai ADF yang didapat berdasarkan pengolahan menggunakan unit root test nilai mutlak yang diperoleh sebesar 3.235615 lebih tinggi daripada nilai critical value pada tingkat kepercayaan 5\% yaitu nilai mutlaknya sebesar -2.906210 .

Pengujian yang dilakukan pada variabel Dolar AS stasioner pada tingkat level karena nilai mutlak ADF yang didapat sebesar 3.276471 lebih tinggi daripada nilai mutlak critical value pada tingkat kepercayaan 5\% yaitu -2.906210 sehingga tidak perlu dilakukan first differencing karena data telah stasioner pada tingkat level.

Berdasarkan hasil perhitungan diperoleh kesimpulan bahwa hasil estimasi kausalitas Granger menunjukkan bahwa pada Hipotesis yang menyatakan Emas tidak menyebabkan Dolar AS Emas ditolak, hal ini dapat dilihat F statistik yang signifikan pada tingkat kesalahan 5\% yaitu sebesar 0.000. Artinya kenaikan harga Emas menyebabkan kenaikan harga Dolar AS. Sebaliknya, hipotesis yang menyatakan bahwa Dolar AS tidak menyebabkan emas diterima, karena F statistik yang tidak signifikan pada alfa 5\% yaitu sebesar 0.67730 . Artinya kenaikan atau penurunan harga Dolar AS menyebabkan penurunun/kenaikan harga emas.

Dari hasil uji kausalitas Granger diketahui bahwa estimasi kausalitas menunjukkan harga emas mempengaruhi harga Dolar. Sementara nilai tukar Dolar AS tidak mempengaruhi harga emas. Artinya, Dinar emas mempengaruhi nilai tukar Dolar AS dan harga Dolar AS tidak mempengaruhi nilai riil emas. Ini berarti volatilitas harga Dolar AS dipengaruhi volatiltas Dinar emas dan volatilias Dolar AS tidak dipengaruhi Dinar emas. Jika trend volatilitas Dinar emas tidak stabil, berarti dapat disimpulkan bahwa volatiltas Dolar AS juga tidak stabil. Tetapi, jika Dolar AS tidak stabil belum tentu Dinar emas tidak stabil.

Untuk melihat tingkat stabilitas nilai tukar Dolar AS dan Emas dapat dilakukan dengan Uji variance kedua variabel tersebut. Dari hasil uji variance terhadap dua variabel di atas dapat diketahui bahwa nilai variance Dolar AS periode Januari 2001-Juli 2006 yakni 541634.3 dan variance Dinar emas yakni 1,884,190,602.14 sedangkan nilai mean masing-masing variabel, untuk Dolar AS sebesar 9367 dan mean Dinar emas 112693.

Perbedaan nilai mean yang begitu jauh tidak dapat dibandingkan dispersi datanya secara langsung. Oleh karena itu, untuk menghitung nilai variance harus diakarkan kembali menjadi deviasi standar supaya ukuran dispersi menjadi jelas.

Dari hasil uji dengan deviasi standar diperoleh nilai standar deviasi variabel Dolar AS sebesar 735.9581 dan nilai standar deviasi untuk emas sebesar 43407. 
Namun, karena nilai mean dari Dolar AS sebesar 9039 dan nilai mean dari Dinar emas sebesar 112693.yang berbeda maka tidak dapat diambil kesimpulan dari hasil uji variance tersebut. Untuk itu, dilakukan Uji 2 Analisis of Variance (ANOVA). Dalam bentuk yang paling sederhana, Anova ini digunakan untuk menguji signifikansi dari perbedaan dua rata-rata dari sejumlah populasi yang berbeda.

Dari hasil uji analysis of variance (ANOVA) dapat diambil kesimpulan bahwa Dinar emas lebih stabil dari pada Dolar AS. Hal ini dapat dilihat dari hasil uji analysis of variance (ANOVA), yakni pada area reject $H_{0}$. Hal ini dapat dilihat dari nilai F-Statistik 379.532 lebih besar dari pada Critical Value 3.99. dan nilai signifikansi yang ditampilkan oleh e-views yakni 0.000. Dari hasil uji statistik di atas diambil kesimpulan bahwa volatilitas Dinar emas lebih stabil dari Dolar AS.

\section{SIMPULAN}

Hasil perhitungan laju pertumbuhan Dolar AS secara bulanan selama periode penelitian menunjukan bahwa laju pertumbuhan harga Dolar AS per Bulan sekitar $0.4 \%$. Sementara itu, laju pertumbuhan emas per bulan sekitar $2 \%$ selama periode penelitian. Dari hasil pengujian di atas, dapat diambil kesimpulan bahwa laju pertumbuhan emas lebih tinggi daripada laju pertumbuhan Dolar AS.

Dari hasil uji kausalitas Granger diperoleh kesimpulan bahwa hasil estimasi kausalitas Granger menunjukkan bahwa pada Hipotesis yang menyatakan Emas tidak menyebabkan Dolar AS emas ditolak, hal ini dapat dilihat F statistik yang signifikan pada alfa 5\% yaitu sebesar 0.000. Artinya kenaikan harga Emas menyebabkan kenaikan harga Dolar AS. Sebaliknya, hipotesis yang menyatakan bahwa Dolar AS tidak menyebabkan emas diterima, karena F statistik yang tidak signifikan pada alfa 5\% yaitu sebesar 0.67730 . Artinya kenaikan atau penurunan harga Dolar AS tidak menyebabkan penurunun/kenaikan harga emas.

Volatilitas harga Dolar AS dipengaruhi volatiltas Dinar emas dan volatilias Dinar emas tidak dipengaruhi Dolar AS. Jika trend volatilitas Dinar emas tidak stabil, berarti dapat disimpulkan bahwa volatiltas Dolar AS juga tidak stabil. Tetapi, jika Dolar AS tidak stabil belum tentu Dinar emas tidak stabil.

Hasil uji analysis of variance (ANOVA) dapat diambil kesimpulan bahwa Dinar emas lebih stabil dari pada Dolar AS. Hal ini dapat dilihat dari hasil uji analysis of variance (ANOVA), yakni pada area reject $H_{0}$. Hal ini dapat dilihat dari nilai F-Statistik 379.532 lebih besar dari pada Critical Value 3.99. dan nilai signifikansi yang ditampilkan oleh e-views 5 yakni 0.000 . Secara keseluruhan disimpulkan bahwa pada periode penelitian Dinar emas bisa dijadikan alternatif pengganti Dolar AS karena nilainya yang stabil yang diukur dengan Rupiah. 


\section{PUSTAKA ACUAN}

Ahmed, H. 2002. "Money and Exchange Rate in Islamic Economy", hasil Seminar Stable and Just Global Monetary System, Viability Of The Islamic Dinar. Malaysia: IIUM.

Al Arif, M. N. R. 2010. Teori Makroekonomi Islam. Bandung: Alfabeta. . 2011. Dasar-dasar Ekonomi Islam. Surakarta: Era Intermedia.

Chapra, M.U. 2000. Sistem Moneter Islam. Jakarta: Gema Insani Press.

Choudhury, M.A. 1997. Money in Islam. Canada: Routledge.

Esquivel, G \& F.B. Larrain. 2002. The Impact of G-3 Exchange Rate Volatility on Developing Countries. G-24 Discussion Paper Series, United Nations New York and Geneva.

Hakim, C.M.. 2001. Sistem Dinar Solusi Perbankan Syariah, dalam Buku Dinar emas Solusi Krisis Moneter. Jakarta: PIRAC, SEM Institut, Jakarta.

Hamidi, M. 2007. Gold Dinar Sistem Moneter Global yang Stabil dan berkeadilan. Cet. Ke-1. Jakarta: Senayan Abadi Publishing.

Hasan, A. 2005. Mata Uang Islami Telaah Komprehensif Sistem Keuangan Islami. Jakarta: PT. Raja Grafindo Persada.

Huda, N, dkk. 2008. Ekonomi Makro Islam: Pendekatan Teoritis. Jakarta: Kencana.

Mannan, M.A. 1992. Ekonomi Islam: Teori dan Praktik. Jakarta: Intermasa.

Marthon, S.S. 2004. Ekonomi Islam: Di Tengah Krisis Ekonomi Global. Jakarta: Zikrul Hakim.

Metwally, M. M. 1993. Essays on Islamic Economics. Calcutta: Academic Publisher

Muhammad. 2002. Kebijakan Fiskal dan Moneter dalam Ekonomi Islam. Yogyakarta: UII Press.

Paolo P. \& C. Tile. 2003. Aspek Ekonomi dari Krisis Mata Uang dan Penularannya: Suatu Pengantar, dalam Sofyan S. Harahap, Pelajaran dari Krisis Asia. Jakarta: Quantum.

Perwataatmadja, A.K. 2003. Menggagas Ekonomi Syariah Yang Mantap dengan Peraturan Perundang-undangan yang Baik, Seminar Nasional Hukum Ekonomi, Senat Mahasiswa Fakultas Hukum Universitas Indonesia, tanggal 25-27 Februari 2003, Kampus UI Depok.

Siregar, M. 2002. Ekonomi dan Bank Syariah Pada Millenium Ketiga. Medan: IAIN Press.

Supriyanto, E. 2005. Ekonomi Islam: Pendekatan Ekonomi Makro Islam dan Konvensional. Bandung: Graha Ilmu.

Yusanto, Ismail. 2001. Mencari Solusi Krisis Ekonomi, dalam buku Dinar emas Solusi Krisis Moneter. Jakarta: PIRAC SEM Institut. 